\title{
Multidirectional Activities for Gene Pool Conservation in GCEARS-PSP
}

\author{
Daniel Severus DEZMIREAN ${ }^{1}$, Liviu Alexandru MARGHITAȘ ${ }^{1}$, Otilia BOBIȘ ${ }^{2}$, Adriana Cristina URCAN ${ }^{1}$, \\ Horatiu DEZMIREAN ${ }^{3}$, Claudia PAȘCA ${ }^{1}$, Adela Ramona MOISE ${ }^{1 *}$ \\ ${ }^{1}$ Department of Apiculture and Sericulture, University of Agricultural Science and Veterinary Medicine, \\ 3-5 Mănăştur Street, 400372 Cluj-Napoca, Romania \\ ${ }^{2}$ Life Sciences Institute "King Michael I" of Romania, University of Agricultural Sciences and Veterinary \\ Medicine, 3-5 Mănăştur Street, 400372 Cluj-Napoca, Romania \\ ${ }^{3}$ Department of Horticulture, University of Agricultural Science and Veterinary Medicine, 3-5 Mănăştur \\ Street, 400372 Cluj-Napoca, Romania \\ *corresponding author: adela.moise@usamvcluj.ro
}

Bulletin UASVM Animal Science and Biotechnologies 75(1)/ 2018

Print ISSN 1843-5262; Electronic ISSN 1843-536X

DOI:10.15835/buasvmcn-asb: 000218

\begin{abstract}
The Global Centre of Excellence for Advance Research in Sericulture and Promotion of Silk Production (GCEARS-PSP), recognised by ISC since 2014, was created with the main purposes: development of advanced research in sericulture and diagnostic services using modern techniques, achievement of a gene pool of different silkworms races and promotion of silk production. The objective of this study was to characterize the races from the GCEARS-PSP, in order to conserve the most valuable and resistant ones. This characterisation is a part of GCEARSPSP's strategy for the revival and development of sericulture and silk production in Romania. The GCEARS-PSP represents an important point of reference for Romanian sericulture. The experimental data described showed a good prospective for a proper functioning of the research centre and the obtained results are promising for the next lines of research.
\end{abstract}

Keywords: conservation, GCEARS-PSP, silkworm, breeds

\section{INTRODUCTION}

The Global Centre of Excellence for Advance Research in Sericulture and Promotion of Silk Production (GCEARS-PSP), recognised by ISC since 2014, was created with the main purposes: development of advanced research in sericulture and diagnostic services using modern techniques, achievement of a gene pool of different silkworms races and promotion of silk production.

GCEARS-PSP works in UASVM CN with the main aim of Romanian sericulture revival.

Multidirectional approaches for achieving the goals are:

Analyze the sericulture revival's possibilities in Romania;
Standardization of phenotypic characteristics of autochthones races and hybrids and theirs exploitation in MSF (familial sericulture module);

Identification of the areas with sericulture potential in Romania;

Creation of new models for sericulture farms establishment, having a good practical applicability in sericulture entrepreneurship;

Real consultancy and support for the farmers;

Analyze the silkworm's and mulberry's pathogens, using classical and specialized laboratory techniques, including the molecular genetics ones.

The objective of this study was to characterize the races from the GCEARS-PSP, in order to 
conserve the most valuable and resistant ones and further to create the next generations of hybrids. This characterization is part of GCEARSPSP's strategy for the revival and development of sericulture and silk production in Romania.

\section{MATERIALS AND METHODS}

Bombyx mori races with white and color silk cocoons from GCEARS-PSP, and with different country origins, were studied for the main race parameters.

During trials, the larvae samples (200 for every race) have been bred under controlled temperature and humidity conditions, using a well knowing and already standardized method (Mărghitaş, 1992; Mărghitaş, 1995; Mărghitaşet al., 2003); the measurements of followed parameters (incubation and hatching of the silkworm eggs, the evolution of the larvae stages, and the biological indices of the crude cocoons) were done on 20 randomized picked up larvae.

The most important materials used in experimental breeding organization are:

- Mulberry plantation, which provides the silkworm food - mulberry leaves; the mulberry leaves from UASVM CN plantation were used;

- The room for silkworm's experimental series;

- Growing modules (MSF- Familial Sericulture Modules);

- Paper and cocoons making materials.

A series of work methods were applied during silkworm's breeding, everyone having important and direct implications in achieving the final goal of experimental trails, meaning the obtainment of high quality and quantity of cocoons. The parameters of temperature and humidity were registered three times per day, and the conditions established before (Bojan et al., 2007) were respected.

The determination of the main parameters were developed using recognized methods (Dezmirean, 2013; Bentea, 2006). Similar studies regarding biological parameters of Bombyx mori development were done by Hussain et al., 2011.

\section{RESULTS AND DISCUSSIONS}

The main characteristics followed in the experimental year 2017 were: incubation and hatching of the silkworm eggs, the evolution of the larvae stages, and the biological indices of the crude cocoons with different origin. There are just a few scientifically reports regarding the European breeds of silkworms, but we have to mention the study of Tzenov et al. (2015), which demonstrated the good productive characters values in Bulgarian x Italian hybrids.

All results were statistically processed and are in the range of race parameters, demonstrating that the gene pool of Bombyx mori is valuable for the next experimental research and suitable for breeders supply.

\section{Hatching percent}

The hatching percent [(number of hatching eggs*100)/number of eggs/hatching)] is an important breed character, it characterize the race and has an important role in selection and amelioration of silkworm breeds and varieties. In table 1 the results regarding the prolificacy and hatching percent of 24 pure races and hybrids are presented; table 2 summarize the statistical parameters of its.

The biggest number of eggs per hatching was registered at Chinese race $\mathrm{P} 4 / \mathrm{T}$ (668) and the smaller one at the Russian one US4 (512), but the hatching percent depends on the number of hatching eggs, as well.

Anyway, the highest hatching percent at Romanian breeds was registered at $\mathrm{AO}_{33}$ race, even if the average of eggs/number was the smallest one. The prolificity and hatching percent are characters that were studied by other authors at Romanian breeds and hybrids. Comparing these data (Benţea, 2006), we can state that only few differences are registered regarding the hatching percent: at $\mathrm{AB}$ a difference of $1.45 \%$, at $\mathrm{AC}_{29}$ a difference of $4.85 \%$ and at $B_{75}-0.94 \%$.

With such a little difference of percentage, the hatching percent represent one of the most stable race characters in silkworm characterization, and once again we can state that is one of the selection criteria in amelioration or hybrid's obtainment. This is hardened by the variability coefficient which is very low (0.39 to $3.26 \%$ ), demonstrating at the autochthonous races, as well as the foreign ones, that the experimental groups were homogeneous.

Anyhow, regarding the foreign races and hybrids studied here, the issue of data comparison remains unsolved, due to the lack of scientifically reports; studying these foreign races founded in GCEARS-PSP gene pool, is one of our objectives for the next years. 
Table 1. Prolificacy and hatching percent of studied silkworm breeds

\begin{tabular}{|c|c|c|c|c|c|}
\hline Origin & Breeds & $\begin{array}{c}\text { Number of eggs/ } \\
\text { hatching }\end{array}$ & $\begin{array}{c}\text { Number of hatching } \\
\text { eggs }\end{array}$ & $\begin{array}{c}\text { Hatching percent } \\
\%\end{array}$ & $\begin{array}{c}\text { Number of } \\
\text { unhatching eggs }\end{array}$ \\
\hline \multirow[t]{6}{*}{ Romania } & $\overline{\mathrm{AB}}$ & 627 & 597 & 95.22 & 30 \\
\hline & $\mathrm{AC}$ & 609 & 588 & 96.55 & 21 \\
\hline & $\mathrm{AC}_{9}$ & 608 & 581 & 95.56 & 27 \\
\hline & $\mathrm{B}_{75}$ & 529 & 499 & 94.33 & 30 \\
\hline & $\mathrm{AO}_{23}$ & 514 & 500 & 97.28 & 14 \\
\hline & $\mathrm{S}_{73}$ & 585 & 550 & 94.02 & 35 \\
\hline China & $\mathrm{P} 4 / \mathrm{T}$ & 668 & 638 & 95.51 & 30 \\
\hline France & Var & 610 & 587 & 96.23 & 23 \\
\hline \multirow{5}{*}{ Uzbekistan } & B2 & 604 & 579 & 95.86 & 25 \\
\hline & S9 & 531 & 500 & 94.16 & 31 \\
\hline & S21 & 525 & 502 & 95.62 & 23 \\
\hline & S8 & 589 & 559 & 94.91 & 30 \\
\hline & B1 & 520 & 489 & 94.04 & 31 \\
\hline \multirow[t]{3}{*}{ Japan } & Kempaku & 594 & 555 & 93.43 & 39 \\
\hline & C127 & 665 & 645 & 96.99 & 20 \\
\hline & C122 & 612 & 580 & 94.77 & 32 \\
\hline \multirow[t]{2}{*}{ Italy } & AJ17 & 604 & 580 & 96.03 & 24 \\
\hline & AJ2 & 541 & 510 & 94.27 & 31 \\
\hline \multirow[t]{4}{*}{ Rusia } & US4 & 512 & 489 & 95.51 & 23 \\
\hline & SK2 & 587 & 549 & 93.53 & 38 \\
\hline & V39 & 654 & 624 & 95.41 & 30 \\
\hline & S17 & 579 & 540 & 93.26 & 39 \\
\hline Ucrania & $\mathrm{U} 2$ & 624 & 587 & 94.07 & 37 \\
\hline Indonesia & N1 & 620 & 579 & 93.39 & 41 \\
\hline
\end{tabular}

Table 2. Averages and dispersion parameters calculated for hatching percent at pure breeds and hybrids

\begin{tabular}{cccccccc}
\hline Breed/Hybrids & $\bar{X}$ & sd & V\% & $\begin{array}{c}\text { Breed/ } \\
\text { Hybrids }\end{array}$ & $\bar{X}$ & sd & V\% \\
\hline $\mathbf{A B}$ & 95.22 & 1.76 & 1.84 & B1 & 94.04 & 2.28 & 2.36 \\
\hline $\mathbf{A C}$ & 96.55 & 1.23 & 1.27 & Kempaku & 93.43 & 3.04 & 3.26 \\
\hline $\mathbf{A C}_{29}$ & 95.56 & 2.45 & 2.57 & $\mathrm{C} 127$ & 96.99 & 2.74 & 2.89 \\
\hline $\mathbf{B}_{75}$ & 94.33 & 2.95 & 3.14 & $\mathrm{C} 122$ & 94.77 & 1.53 & 1.62 \\
\hline $\mathbf{A 0}_{33}$ & 97.28 & 3.49 & 3.26 & AJ17 & 96.03 & 0.93 & 0.98 \\
\hline $\mathbf{S}_{76}$ & 94.02 & 1.18 & 1.23 & AJ2 & 94.27 & 1.24 & 1.29 \\
\hline $\mathbf{P 4 / T}$ & 95.51 & 0.37 & 0.39 & US4 & 95.51 & 1.60 & 1.68 \\
\hline Var & 96.23 & 1.68 & 1.72 & SK2 & 93.53 & 1.96 & 2.06 \\
\hline B2 & 95.86 & 0.97 & 1.01 & V39 & 95.41 & 2.96 & 2.98 \\
\hline S9 & 94.16 & 0.52 & 0.55 & S17 & 93.26 & 2.04 & 2.19 \\
\hline S21 & 95.62 & 1.46 & 1.64 & U2 & 94.07 & 1.10 & 1.19 \\
\hline S8 & 94.91 & 2.11 & 2.18 & N1 & 93.39 & 1.08 & 1.52 \\
\hline
\end{tabular}

\section{Evolution of larvae stages}

For characterize the larvae stage of Bombyx mori races and hybrids the main characteristics were the weight of larvae in the $V^{\text {th }}$ instar and the length of it's in the $\mathrm{IV}^{\text {th }}$ and $\mathrm{V}^{\text {th }}$ instars.

The weight of 20 heads/breed or hybrid were determined using an analytical balance; the weight was determined in the $2^{\text {nd }}$ and in the $5^{\text {th }}$ day of the $\mathrm{V}^{\text {th }}$ instar and the percent of weight development was calculated; the results regarding this parameter are presented in figure 1 . Due to the fact that the larval stage is pretty long (between 25 and 35 days) and depends by a lot of factors (race/ hybrid, food quality and quantity, microclimate conditions), the measurements of weight and length are done two times during the fifth stage of development. The microclimate conditions, especially temperature influence on larvae stages, 


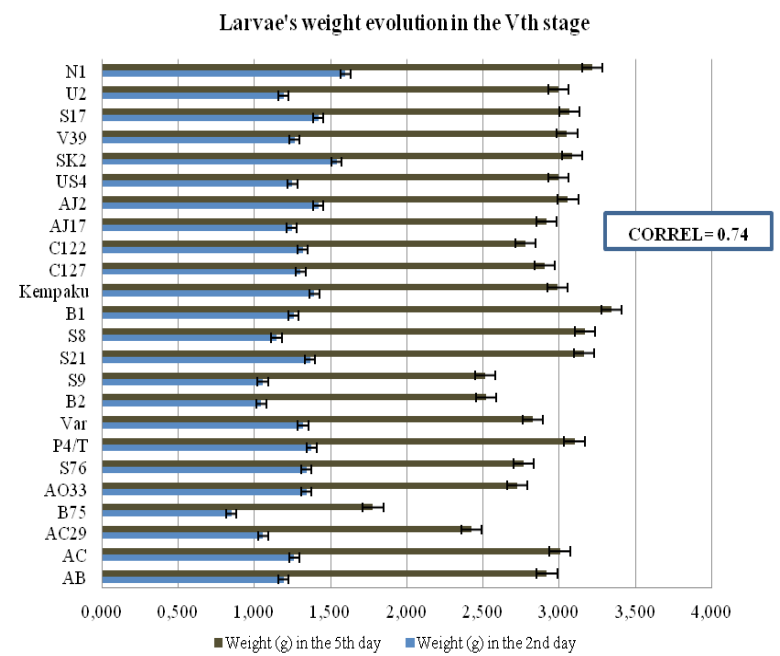

Figure 1. Graphical representation of weight development at Bombyx mori in $\mathrm{V}^{\text {th }}$ instar

Table 3. The average values of the larvae length during $I V^{\text {th }}$ and $V^{\text {th }}$ instar

\begin{tabular}{|c|c|c|c|c|}
\hline \multirow{2}{*}{ Origine } & \multirow{2}{*}{ Breeds } & \multirow{2}{*}{ Length $(\mathrm{mm}) / \mathrm{IV}^{\text {th }}$ stage } & \multicolumn{2}{|c|}{ Length $(\mathrm{mm}) / \mathrm{V}^{\text {th }}$ stage } \\
\hline & & & $2^{\text {nd }}$ day & $5^{\text {th }}$ day \\
\hline \multirow[t]{6}{*}{ Romania } & $\mathrm{AB}$ & $47.270 \pm 0.133$ & $56.040 \pm 0.789$ & $66.650 \pm 0.828$ \\
\hline & $\mathrm{AC}$ & $46.230 \pm 0.544$ & $55.150 \pm 0.312$ & $69.425 \pm 0.696$ \\
\hline & $\mathrm{AC}_{29}$ & $46.412 \pm 0.441$ & $53.199 \pm 0.346$ & $70.250 \pm 0.826$ \\
\hline & $\mathrm{B}_{75}$ & $44.990 \pm 0.061$ & $56.601 \pm 0.311$ & $67.970 \pm 0.780$ \\
\hline & $\mathrm{AO}_{33}$ & $46.550 \pm 0.122$ & $49.380 \pm 0.211$ & $67.581 \pm 0.305$ \\
\hline & $\mathrm{S}_{76}$ & $46.430 \pm 0.208$ & $54.271 \pm 0.588$ & $61.919 \pm 0.332$ \\
\hline China & $\mathrm{P} 4 / \mathrm{T}$ & $46.090 \pm 0.327$ & $58.110 \pm 0.274$ & $67.752 \pm 0.602$ \\
\hline France & Var & $49.271 \pm 0.109$ & $54.832 \pm 0.124$ & $68.561 \pm 0.162$ \\
\hline \multirow[t]{5}{*}{ Uzbekistan } & B2 & $48.845 \pm 0.657$ & $55.615 \pm 0.215$ & $73.271 \pm 0.823$ \\
\hline & S9 & $48.210 \pm 0.154$ & $54.364 \pm 0.402$ & $72.705 \pm 0.602$ \\
\hline & S21 & $38.031 \pm 0.063$ & $57.020 \pm 0.122$ & $70.130 \pm 0.233$ \\
\hline & S8 & $37.659 \pm 0.056$ & $56.722 \pm 0.128$ & $71.480 \pm 0.616$ \\
\hline & B1 & $45.950 \pm 0.325$ & $58.840 \pm 0.154$ & $73.052 \pm 0.254$ \\
\hline \multirow[t]{3}{*}{ Japan } & Kempaku & $42.580 \pm 0.216$ & $54.952 \pm 0.158$ & $76.381 \pm 0.434$ \\
\hline & C127 & $39.540 \pm 0.119$ & $55.520 \pm 0.111$ & $78.516 \pm 0.525$ \\
\hline & C122 & $46.420 \pm 0.140$ & $55.358 \pm 0.125$ & $71.850 \pm 0.468$ \\
\hline \multirow[t]{2}{*}{ Italy } & AJ17 & $47.521 \pm 0.161$ & $56.630 \pm 0.826$ & $74.802 \pm 0.242$ \\
\hline & $\mathrm{AJ} 2$ & $48.435 \pm 0.201$ & $54.191 \pm 0.327$ & $70.499 \pm 0.355$ \\
\hline \multirow[t]{4}{*}{ Rusia } & US4 & $36.102 \pm 0.182$ & $46.916 \pm 0.240$ & $69.396 \pm 0.428$ \\
\hline & SK2 & $46.010 \pm 0.165$ & $55.207 \pm 0.320$ & $69.860 \pm 0.440$ \\
\hline & V39 & $46.555 \pm 0.195$ & $56.590 \pm 0.200$ & $71.554 \pm 0.302$ \\
\hline & S17 & $45.323 \pm 0.128$ & $59.405 \pm 0.412$ & $73.022 \pm 0.409$ \\
\hline Ucrania & $\mathrm{U} 2$ & $44.990 \pm 0.208$ & $57.815 \pm 0.234$ & $67.603 \pm 0.509$ \\
\hline Indonesia & N1 & $38.030 \pm 0.054$ & $56.369 \pm 0.124$ & $70.435 \pm 0.268$ \\
\hline
\end{tabular}


Table 4. The biological indices of crude cocoons

\begin{tabular}{|c|c|c|c|c|}
\hline Origine & Breed & $\begin{array}{l}\text { Weight of crude } \\
\text { cocoons }(\mathrm{g})\end{array}$ & Silk incartment (g) & $\begin{array}{c}\text { Longitudinal and } \\
\text { transversal axes ratio }\end{array}$ \\
\hline \multirow[t]{6}{*}{ Romania } & $\mathrm{AB}$ & $1.677 \pm 0.023$ & $0.360 \pm 0.011$ & 1.825 \\
\hline & $\mathrm{AC}$ & $1.495 \pm 0.019$ & $0.352 \pm 0.010$ & 1.678 \\
\hline & $\mathrm{AC}_{29}$ & $1.586 \pm 0.025$ & $0.345 \pm 0.019$ & 2.285 \\
\hline & $\mathrm{B}_{75}$ & $1.725 \pm 0.051$ & $0.402 \pm 0.015$ & 1.569 \\
\hline & $\mathrm{AO}_{33}$ & $1.225 \pm 0.021$ & $0.385 \pm 0.011$ & 1.578 \\
\hline & $\mathrm{S}_{76}^{35}$ & $1.185 \pm 0.021$ & $0.342 \pm 0.015$ & 1.728 \\
\hline China & $\mathrm{P} 4 / \mathrm{T}$ & $1.802 \pm 0.033$ & $0.364 \pm 0.011$ & 1.809 \\
\hline France & Var & $1.639 \pm 0.031$ & $0.442 \pm 0.015$ & 1.812 \\
\hline \multirow[t]{5}{*}{ Uzbekistan } & $\mathrm{B} 2$ & $1.705 \pm 0.005$ & $0.391 \pm 0.035$ & 1.830 \\
\hline & S9 & $1.701 \pm 0.024$ & $0.342 \pm 0.015$ & 1.827 \\
\hline & S21 & $1.599 \pm 0.015$ & $0.592 \pm 0.017$ & 1.800 \\
\hline & S8 & $1.662 \pm 0.045$ & $0.502 \pm 0.017$ & 1.836 \\
\hline & B1 & $1.622 \pm 0.043$ & $0.360 \pm 0.015$ & 1.845 \\
\hline \multirow[t]{3}{*}{ Japan } & Kempaku & $1.569 \pm 0.034$ & $0.365 \pm 0.005$ & 1.814 \\
\hline & C127 & $1.917 \pm 0.020$ & $0.383 \pm 0.025$ & 1.847 \\
\hline & C122 & $1.457 \pm 0.042$ & $0.523 \pm 0.007$ & 1.768 \\
\hline \multirow[t]{2}{*}{ Italy } & AJ17 & $1.625 \pm 0.030$ & $0.401 \pm 0.006$ & 1.828 \\
\hline & AJ2 & $1.836 \pm 0.026$ & $0.353 \pm 0.065$ & 1.829 \\
\hline \multirow[t]{4}{*}{ Rusia } & US4 & $2.066 \pm 0.031$ & $0.502 \pm 0.007$ & 1.835 \\
\hline & SK2 & $1.419 \pm 0.032$ & $0.478 \pm 0.017$ & 1.721 \\
\hline & V39 & $1.581 \pm 0.033$ & $0.425 \pm 0.006$ & 1.736 \\
\hline & S17 & $1.603 \pm 0.041$ & $0.347 \pm 0.005$ & 1.815 \\
\hline Ucrania & U2 & $1.650 \pm 0.032$ & $0.351 \pm 0.005$ & 1.924 \\
\hline Indonesia & N1 & $1.385 \pm 0.033$ & $0.342 \pm 0.005$ & 1.865 \\
\hline
\end{tabular}

were seriously investigated by Hussain et al. (2011) in Pakistan and Chanda et al. (2013) in India, countries with a long history in sericulture.

Other parameter very important for the larvae stage is the length; the measurements were done for 20 larvae from every experimental group, for three times, using an electronic sliding and the result are presented in table 3 . The biggest value for this parameter is obtained at the Russian race US4; this fact demonstrate once again, that the hatching percent (which at this race was not the biggest one, having only the smaller number of eggs per hatching) is not directly correlated with the length of larvae's.

Correlation between hatching percent, larvae weight and length in the $5^{\text {th }}$ day of $\mathrm{V}^{\text {th }}$ instar were done, and the results showed that the first two parameters are negatively correlated $(-0.13)$, and between the last two ones a positive correlation exist; this result is in accordance with all other authors which studied before these characteristics (Bura et al., 1995; Babu et al., 2001; Bențea et al., 2003; Bențea et al., 2004).

\section{Biological indices of crude cocoons}

The most important parameters of crude cocoons for the race's characterization are the weight of crude cocoons, the weight of silk incartment (the weight of cocoons without chrysalides), and the longitudinal and transversal axes of cocoons. These are parameters that have an important role in technological aspects of silk production and the production of raw silk is directed influenced by those (Singh et al., 1990); the longitudinal and transversal axes of cocoons has an metric role in determination of the cocoons shape (Nishioka et al., 2013), which is one of the breed's character in silkworm selection; the shape and the size of cocoons determine the silk quantity and a positive correlation of shell percent with spinning yield was observed by Sonwalkar (2001); the results of experimental trials obtained in 2017 in GCEARS-PSP are presented in Table 4.

Regarding the weight of crude cocoons, the results have ranged from $1.185 \mathrm{~g}$ (at Romanian $\mathrm{S}_{76}$ race) to $2.066 \mathrm{~g}$ at $\mathrm{US}_{4}$ Russian race. The best weight of silk incartment was registered at Uzbekistanian race $S_{21}(0.592 \mathrm{~g})$ and the most rounded shape of 
cocoons was determined at Romanian $B_{75}$ race (1.569).

\section{CONCLUSIONS}

The GCEARS-PSP represents an important point of reference for Romanian sericulture.

The parameters followed by the research team of GCEARS-PS and presented here are incubation and hatching percent of the silkworm eggs, the evolution of the larvae stages, and the biological indices of the crude cocoons. All these characters are necessary for the characterization of gene pool founded in the custody of the centre, but there are not exhaustive ones, and for this reason more scientifically determinations, including the molecular genetics characterization are needed and have to been done in the near future.

The experimental data described here shows a good prospective for a proper functioning of the research centre and the obtained results are promising for the next lines of research.

\section{REFERENCES}

1. Babu MR, Lakshmi H, Prasad J (2001). Expression of hybrid vigour for silk productivity in silkworm, Bombyx mori L. Journal of Experimental Zoology, 4: 317- 321.

2. Bențea M (2006). Caracterizarea unor hibrizi de viermi de mătase (Bombyx mori L.) crescuţi în zona Transilvaniei. Teză de doctorat. USAMV CN.

3. Benţea M, Mărghitas L. Al, Dezmirean D, Matei A, Szendrei I (2003). Research on the prolificity and the hatching of the breed and hybrid combination of Bombyx Mori L. Bulletin USAMV, 59: 284.

4. Benţea M, Mărghitas L. Al, Dezmirean D, Matei A, Vlaic B (2004). Research upon some morphological traits in Bombyx mori L. Bulletin USAMV-CN, 60: 268-273.

5. Benţea M, Mărghitaş L. Al, Dezmirean D, Matei A, Vlaic B (2005). Cercetări asupra productivităţii unor hibrizi ai viermelui de mătase. Bulletin UASVM- CN, 61: 242 - 246.

6. Bențea M, Mărghitaș L. Al, Dezmirean D, Matei A, Vlaic B (2005). Evolution of some morphological traits in Bombyx mori L. Proceedings of the XXXX Croatian Symposium on Agriculture Opatija.
7. Bojan C, Mărghitaș L. Al, Dezmirean D, Teleky O, Moise A (2007). Qualitative characters study for silkworm hybrids. Bulletin UASVM- CN, 64:1-2.

8. Bura M, Acatincăi S, Pădeanu I (1995). Viermii de mătase, biologie și creștere, Ed. Helicon, Timișoara.

9. Dezmirean DS (2013). Curs de biotehnologii în apicultură şi sericicultură. Ed. AcademicPres Cluj Napoca.

10. Hussain M, Khan SA, Naeem M, Aqil T, Khursheed R, Mohsin A (2011). Evaluation of silkworm lines against variations in temperature and $\mathrm{RH}$ for various parameters of commercial cocoon production. Hindawi Publishing Corporation, Psyche. Volume 2011, Article ID 145640, 11 pages, doi:10.1155/2011/145640.

11. Mărghitaș L. Al, Dezmirean D, Pașca I (2003). Sericicultura, Ed. Mediamira, Cluj- Napoca.

12. Mărghitaș L. Al, Sabău A (1992). Curs de sericicultură, Tipo Agronomia Cluj- Napoca.

13. Mărgitaș L. Al (1995). Creșterea viermilor de mătase, Ed. Ceres, București.

14. Matei A (1994). Studiul comportării unor rase de viermi de mătase de proveniență ucrainiană în condițiile României. Rev. de Medicină veterinară și creșterea animalelor, București, 4-5: 2-4.

15. Nishioka T, Mase K, Kajiura Z, Morishima M, Kudoh T (2013). Shape of Silkworm cocoon changes with size in some races. Journal of Insect Biotechnology and Sericology 82: 55-59.

16. Pașca I (2004). Cercetări privind influența condițiilor de mediu din Zona Transilvaniei asupra unor rase și hibrizi românești de viermi de mătase ai dudului (Bombyx mori L.) Teză de Doctorat Cluj- Napoca, 2004.

17. Singh T, Sinha Deo SN, Das Mamoni (1990). Heterosis in silk productivity as a breeding index in Bombyx mori $\mathrm{L}$. Silk Inform. Bull 3: 1- 3.

18. Sonwalkar TN (2001). Hand Book of Silk Technology, New Age International (P) Limited, New Delhi, 14-21.

19. Subhra C, Lal Mohan S, Nirvan KD, Niharendu BK, Bharat BB (2013). Correlation among Shell Percent, Cocoon yield and reeling parameters of multi $\mathrm{x}$ bi cocoons under different agro-climatic conditions of west bengal, India. International Journal of Industrial Entomology, 26: 74-80.

20. Tzenov P, Cappellozza S, Grekov D (2015). Creation and Testing of Silkworm, Bombyx mori L. F1 Hybrids between Bulgarian and Italian Breeds. Proceedings of $7^{\text {th }}$ BACSA International Conference "Organic Sericulture - Now and the Future" "ORGASERI" 2015, Sinaia, Romania, 132-137. 